\title{
A NEW SPECIES OF FLESHY-FRUITED BEGONIA (BEGONIACEAE) FROM SUMATRA
}

\author{
MARK C. TEBBITT \\ Brooklyn Botanic Garden, 1000 Washington Avenue, Brooklyn, NY 11225, USA
}

\begin{abstract}
SUMMARY
Begonia scottii, a new species of Begonia from northern Sumatra, Indonesia, is described and illustrated. The species is classified in the section Sphenanthera and a key to this and allied species within this section is provided.
\end{abstract}

Key words: Begoniaceae, Begonia section Sphenanthera, Sumatra.

In the most recent infrageneric revision of Begonia L., Doorenbos et al. (1998) recognize 63 sections, together containing almost 1400 species. An additional section has since been added to Begonia following the reclassification of the genus Symbegonia Warb. (Forrest \& Hollingsworth, 2003). Moreover, a new monotypic section Chasmophila was raised to accommodate the continental African species Begonia iucunda Irmsch. (De Wilde \& Plana, 2003). The Begoniaceae, as currently recognized, contains two genera: the species-rich Begonia, which is widely distributed in tropical and subtropical regions of the world; and the monotypic Hillebrandia Oliv., which is endemic to the Hawaiian Islands. Currently 19 sections and approximately 625 species of Begonia are recognized from Asia (Doorenbos et al., 1998; Forrest \& Hollingsworth, 2003), with six of the sections and 36 of the species occurring on Sumatra (Sands, 2001). No floristic account of Sumatran Begonia has ever been published and Sands (2001) suggests that as many as 20 species remain undescribed. This high figure is not surprising given the local endemicity exhibited by many Asian Begonia species and the lack of comprehensive Begonia collections from Sumatra.

Begonia scottii is described here as part of an ongoing taxonomic revision of fleshy-fruited Asian Begonia (Tebbitt \& Dickson, 2000; Tebbitt \& Guan, 2002; Tebbitt, 2003a, b), most of which are classified in the section Sphenanthera (Hassk.) Warb. (Irmscher, 1925; Doorenbos et al., 1998). Among the fleshy-fruited Asian Begonia, B. scottii is closely allied to B. robusta Blume from western Java. Begonia robusta is the type species of section Sphenanthera and shares with the new species several features including a robust habit, fleshy indehiscent fruit, male flowers with 4 tepals, female flowers with 5 tepals and 3-locular ovaries with bifid placentae and 3 styles. Within the section Sphenanthera two other species also exhibit these characteristics and undoubtedly also share a close affinity. These are B. multangula Blume, which is widely distributed within Java and B. chlorocarpa Sands from the Kinabalu Massif of Sabah. A key to this species group is presented after the treatment of Begonia scottii. 
Begonia scottii Tebbitt, spec. nov. - Fig. 1

Begonia robusta Blume affinis sed caulibus repentes, foliis subglabris, fructibus absque alatus vel alatus tantum usque ad $3 \mathrm{~mm}$ longos. - Typus: De Wilde \& De Wilde-Duyfjes 14309 (holo L; iso L), Indonesia, Sumatra, Gunung Ketambe and vicinity, 8-15 km SW from the mouth of Lau Ketambe, c. $40 \mathrm{~km}$ NW of Kutatjane, Camp 5, 1700 m alt., 16 Aug. 1972.

Monoecious decumbent herb. Stem glabrous or with sparse multicellular hairs, usually creeping and rooted at nodes into the substrate for most of its length, aerial portion of stem (when present) to $35 \mathrm{~cm}$ tall. Stipules persistent, glabrous, ovate-lanceolate,

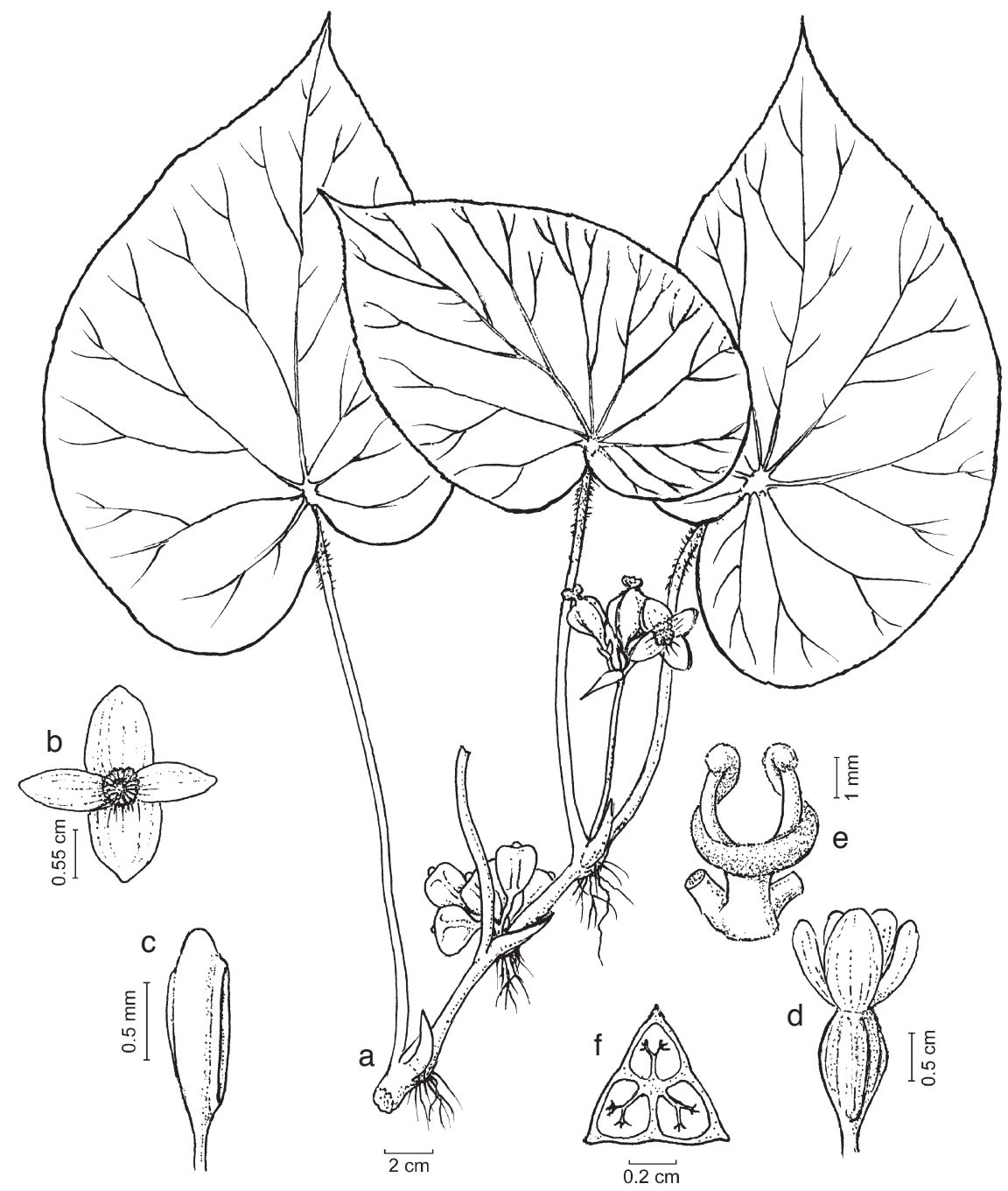

Fig. 1. Begonia scottii Tebbitt. a. Habit; b. male flower; c. stamen; d. female flower; e. style; f. cross section of ovary (a: composite of W.N. \& C.M. Bangham 775 \& 776; b, c, e: W.N. \& C.M. Bangham 776; d, e: De Wilde \& De Wilde-Duyfjes 13531). 
$1.2-2.2$ by $0.5-0.8 \mathrm{~cm}$, apex apiculate, apiculus usually with sparse short glandular unicellular hairs, margin entire. Leaves alternate, held upright: petiole usually covered with long soft reddish multicellular hairs, these especially dense in the upper half, or occasionally with sparse hairs in upper half and glabrous in lower half, (9-)15-60 $\mathrm{cm}$ long, joining blade at an angle; blade asymmetric, both surfaces glabrous or with sparse minute multicellular hairs, main veins sometimes with long soft hairs like those of petiole, ovate, $8-22$ by $6-20 \mathrm{~cm}$, apex gradually or abruptly acuminate, base obliquely cordate, veins palmate, $6-8$, margin occasionally shortly lobed, serrulate, teeth tipped by short glandular hairs. Inflorescence axillary, erect, cymose, bisexual. Bracts persistent while flowering but eventually falling, glabrous, elliptic, $0.8-1.6$ by $0.4-0.5 \mathrm{~cm}$, margin entire, with short glandular hairs. Pedicels: those of male flowers $1.5-2.5 \mathrm{~cm}$ long, with sparse unicellular hairs, those of female flowers $0.7-1.8$ $\mathrm{cm}$ long, glabrous. Male flowers: tepals 4, white to pink-red, outer pair ovate, 1.2 by $0.6-1.1 \mathrm{~cm}$, outer surface villous, apex rounded, base rounded, margin entire, inner pair oblong-ovate, $0.9-1.2$ by $0.7-0.8 \mathrm{~cm}$, outer surface glabrous, apex acute, base rounded, margin entire; stamens c. 75, arranged in a hemispherical cluster, actinomorphic, filaments free, $2.5-3 \mathrm{~mm}$ long, anthers elliptic to elliptic-obovate, $1-1.5 \mathrm{~mm}$ long, dehiscing via lateral slits, connectives projecting, rounded. Female flowers: bracteoles absent; tepals 5, entire, the outer ones villous on their outer surfaces, elliptic-obovate, subequal, $1-1.3$ by $0.5-0.9 \mathrm{~cm}$, apex rounded, base cuneate; ovary fleshy, with sparse hairs, suborbicular, $0.5-0.8 \mathrm{~cm}$ in diameter, wingless or occasionally with 3 subequal rounded-triangular wings to $3 \mathrm{~mm}$ long, 3-locular; placentae axile, bifid, bearing ovules on both surfaces; styles 3 , greenish yellow, shortly fused at base, bifid, c. $5 \mathrm{~mm}$ tall, c. $8 \mathrm{~mm}$ wide at apex, stigmatic papillae in a spiral band. Infructescence $3-11$-fruited; pedicels to $3.5 \mathrm{~cm}$ long; fruit indehiscent, fleshy, red to purple-red, with sparse hairs, suborbicular, $1-1.5 \mathrm{~cm}$ in diameter, wingless or occasionally with three subequal blunt wings, wings to 3 by $7 \mathrm{~mm}$.

Distribution - Northern Sumatra.

Habitat \& Ecology - Montane rain forest. Elevation 1125-1750 m. Terrestrial or occasionally growing upon dead fallen tree trunks.

Etymology - Named in honour of Mr. W. Scott Hoover who in recent years has collected Begonia extensively throughout Indonesia.

Additional specimens examined:

W.N. \& C.M. Bangham 775, 776 (A); De Wilde \& De Wilde-Duyfjes 13531 (K, 2 sheets L), 16434 (L).

\section{KEY TO BEGONIA SCOTTII AND ALLIED SPECIES OF BEGONIA SECTION SPHENANTHERA}

1a. Stem erect to $2 \mathrm{~m}$ tall, basal portion not creeping along the ground . . . . . . 2

b. Stem at least at its base creeping along the ground and rooting into the substrate, aerial portion of stem (when present) to $35 \mathrm{~cm}$ tall . . . . . . . . . . 3

2a. Leaf blades above with long red glandular hairs, margin entire or with short rounded lobes; peduncle of infructescence usually at least four times longer than pedicels; fruit usually with one longer wing and two shorter wings or ribs ....

B. robusta 
b. Leaf blades glabrous above or with short to long white or red glandular hairs, margin with several short angular lobes; peduncle of infructescence usually less than three times as long as pedicels; fruit with three equal ribs or short thickened

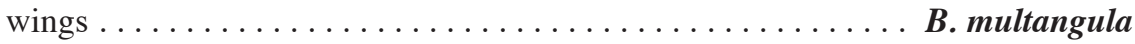

3a. Leaf blades covered with a villous indumentum; ovary with 3 narrow thickened wings up to $1.4 \mathrm{~cm}$ long; fruit green at maturity . . . . . . . B. chlorocarpa

b. Leaf blades lacking a villous indumentum or villous indumentum present only on the main veins; ovary usually lacking wings or occasionally with 3 broad wings

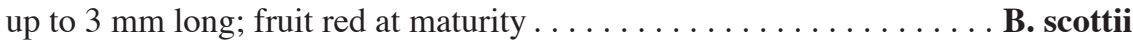

\section{ACKNOWLEDGEMENTS}

I am grateful to Mr. Paul Harwood who provided the illustration and to Drs. Kerry Barringer and Laura Forrest for their comments on an earlier draft of this paper. The curators of $\mathrm{A}, \mathrm{K}$ and $\mathrm{L}$ are thanked for allowing me to examine herbarium material.

\section{REFERENCES}

De Wilde, J.J.F.E. \& V. Plana. 2003. A new section of Begonia (Begoniaceae) from West Central Africa. Edinburgh J. Bot. 60: 121-130.

Doorenbos, J., M.S. M. Sosef \& J.J.F.E. de Wilde. 1998. The sections of Begonia including descriptions, keys and species lists (Studies in Begoniaceae VI). Wageningen Agricultural University Papers 98-2.

Forrest, L.L. \& P.M. Hollingsworth. 2003. A recircumscription of Begonia based on nuclear ribosomal sequences. Pl. Syst. Evol. 241: 193-211.

Irmscher, E. 1925. Begoniaceae. In: A. Engler \& K. Prantl (eds.), Nat. Pflanzenfam., 2nd ed.: 548-588. Engelmann, Leipzig.

Sands, M.J.S. 2001. Begoniaceae in the Flora Malesiana region. In: L.G. Saw, L.S.L. Chua \& K.C. Khoo (eds.), Taxonomy: The cornerstone of biodiversity. Proceedings of the fourth International Flora Malesiana Symposium 1998. 161-168. Forest Research Institute Malaysia, Kuala Lumpur.

Tebbitt, M.C. 2003a. Taxonomy of Begonia longifolia Blume (Begoniaceae), and related species. Brittonia 55: 19-29.

Tebbitt, M.C. 2003b. Notes on south-eastern Asian Begonia (Begoniaceae). Edinburgh J. Bot. 60: $1-9$.

Tebbitt, M.C. \& J.H. Dickson. 2000. Amended descriptions and revised sectional assignment of some Asiatic Begonias (Begoniaceae). Brittonia 52: 112-117.

Tebbitt, M.C. \& K.-Y. Guan. 2002. Emended circumscription of Begonia silletensis (Begoniaceae) and description of a new subspecies from Yunnan, China. Novon 12: 133-136. 